\title{
Adaptive Mobile Learning Application As An Innovative Learning Media To Support The Quality Of Blended Learning Process
}

\author{
$1^{\text {st }}$ Ence Surahman ${ }^{1}, 2^{\text {nd }}$ Walid Fajar Antariksa ${ }^{1}$ \\ \{ence.surahman.fip@um.ac.id ${ }^{1}$, walidfjr@mpi.uin-malang.ac.id ${ }^{1}$ \} \\ Universitas Islam Negeri Maulana Malik Ibrahim, Malang, Indonesia ${ }^{1}$
}

\begin{abstract}
Adaptive mobile learning is a mobile learning application based on an Android operating system that can facilitate the diversity of student learning preferences. Adaptive mobile learning is a learning media innovation in the practice of mobile learning. This study aims to: (1) developing an Adaptive Mobile Learning (Amol) application based on Android system which meets the eligibility criteria according to media validators, materials and responses from users; and (2) knowing the benefits of Amol in improving student learning outcomes and Amol abilities in supporting quality blended learning processes. This study uses a research and development model developed by Alessi Trollip which consists of the planning, design and development stages. The initial product was validated by media and material experts and then revised (alpha test). Then in the beta phase, the product test was tested by several students and continued to test small class products to as many as 30 students. After that, the final test is done. The result of the research showed that: (1) Amol products meet the criteria of being eligible as an innovative learning media with the average score of 3.34 with category of "very good"; and (2) Amol product utilization is seen from the difference in student learning outcomes scores in pre-test and post-test with an average increase of 33.81 after using Amol products in all learning style groups, and the ability of Amol products to support the improvement of the quality of the blended learning process with an average score of 3.41 in the "very good" category.
\end{abstract}

Keywords: adaptive mobile learning, innovative learning media, quality of blended learning process.

\section{Introduction}

Learning is a process to achieve the specified competency targets. In achieving the lecture competency target, the right learning media and model is needed. The learning media that is considered suitable according to the results of the study in previous research is adaptive mobile learning and blended learning.

The rising number of smartphone and Android mobile devices has positive and negative effect. The positive effects are access to information and communication more fast, easy and efficient. Then, there are increasing of sending a document, promoting in internet and media social. It also helps the human work in many fields. In contrast, it also makes negative effects, such as wasting time, for example, social media activity, chatting via instant messaging and games. 
It needs innovation on the media learning development to support the learning process and assist the student to reach the goal of learning. In the learning process, the media has an important role in delivering information to the student. Degeng explains the learning media is a component's strategy in delivering and contain a message which is being delivered to student, i.e., person, tool or material [1].

Learning media has contributions on standard in learning process, learning process will be more interesting, learning process become more interactive by applying theory, shorter of learning's time, increasing learning quality, learning process can be in anywhere and everywhere, increasing the students' positive attitude toward the learning material and learning process, and the teacher's role will be positively to change [2].

In developing multimedia, it needs some principle. Mayer explains six principles in learning media development. They are the principle of space, the principle of time, the principle of coherence, the principle of modality, the principle of redundancy and individual differentiate principle [3].

Based on the background, the problem statements of this research are; (1) How do to produce a feasible adaptive mobile learning product on Biology subject in Senior High School? (2) How are the usefulness of adaptive mobile learning product on Senior High School to increase the student learning outcome and support the blended learning process?

This research aims to: (1) producing Adaptive Mobile Learning (Amol) which meet the criteria and appropriateness based on assessment form media experts, material experts, and student as users; and (2) knowing the usefulness of the Amol product seen from the completeness of the student learning results and ability the product to support the quality blended learning process.

\section{Literature Review}

Mobile learning needs media with technology to make communication between teacher and student. Media in mobile learning should have the criteria; support the lifelong learning, is created based on the user mobility, able to privately used, is supported by technology in a certain activity, and applied student-centered learning.

Learning media not only has a function to deliver the learning information to the student but also to make ease for the student in understanding the material and increase the student's motivation for learning [4]. In short, learning media will make ease the student in understanding the learning material and increase the students' learning outcome.

Recently, the innovation in learning media is demanded to be creative and appropriate with the science and technology development. The development of mobile device gives an opportunity in developing the mobile learning media.

Mobile learning is learning through a mobile device. Mobile learning makes easy the student to learn in everywhere and whenever. The strategy makes easy the student in learning to understand completely in a shorter time than other media. Mobile learning is growing rapidly - not only in terms of applications but also in terms of philosophy and standards. [5].

The good development of mobile learning multimedia can fulfill the personalized learning principle [6]; which is according to the student's characteristic [7]. One of student's characteristic is the unique characteristic among the students in the initial capability, how long they mastery the material, and student learning style [8] [7]. Mobile learning multimedia 
which able to adaptive with the differences of student learning style characteristic called as adaptive mobile learning.

Huang, Wang \& Hsieh explain, to facilitate the various mobile devices, it needs to increase the learning's comfort and efficiency in the mobile learning space [9]. Moreover, it needs to identify the capability of each mobile device and set the material content which provides a solution to various user of the mobile device. In summary, there needs a learning diagnostic mechanism to understand the student's basic knowledge and learning style [10].

Adaptive mobile learning is learning program multimedia which displays the learning material through a mobile device and can adaptive to the student learning style. The capability is made through a special feature of instrument multimedia program to measure the user learning style before accessing the material room [8]. In short, users learn according to their learning style.

Ozyurt states that learning is a complex and difficult process [8]. Some parameters need to consider on student's characteristic, such as students' perception and knowledge, general skill, the developmental potency and environmental factor which has an important role on every single of the learning process. In the learning process, the teacher should understand the dominant character of their student. And then, the learning process can be appropriate with the dominant characteristic. One of the student characteristics that need to consider is the differences in learning style. Student learning style is different among the students [6].

The differences in student learning style may influence the time of understanding and mastering the information. Learning style is ways of student in learning something, related to the ways, approach, and learning experience of students in using information. There are many perspectives about the student learning style, whether it is the genetic factor or depend on the brain which is easy to receive and respond the information management [11]. But, there are some possibilities of learning style which are produced by the interaction between the genetic and learning experience.

In researches, it concluded that adaptive mobile learning was effective in helping the students to reach the learning goal in effective and efficient [6]. Moreover, adaptive mobile learning made ease the learning process because the learning process can be in everywhere and every time. Users can use the product to learn in everywhere and every time according to the need.

Developed adaptive mobile learning product aims to become alternative media in learning. And then, the media are expected able to support the blended learning. The blended learning process is learning process with blend the conventional learning model and learning media by information and communication technology (ICT) assisted. The ICT is the developed adaptive mobile learning product. According to Wahyuningsih \& Budiningsih, blended learning can increase the conceptual understanding and independent learning [12].

Learning using mobile learning media makes the learning more interesting and fun [13] [4]. The learning process will be more effective if the students are fun and pleasant. In contrast, the learning is not optimal when the students are fear, worry, and not comfortable.

There are nine points in measuring the quality of learning multimedia. (1) involve the student in using media, (2) gives free choice of student learning style, (3) train almost on learning domains (cognitive, affective and psychomotor), (4) gives an realistic example by video slide, (5) raise the student learning motivation through composition, color, graph, sound, music, animation, and video, (6) more interactive through the availability buttons in giving the student's respond, (7) aim on individual learning by giving free choice to student appropriate with capability, (8) consistent in media layout (9) able to control according to time of how fast the student think. 
Based on previous statements, concluded that the evaluation criteria on adaptive mobile learning multimedia needs to considers the points of; (1) the appropriate between material and curriculum in syllabus and lesson plan, (2) the appropriateness of material and problem analysis and students need (3) the capability of developed adaptive mobile learning in giving free choice of learning styles to users, (4) the capability of developed adaptive mobile learning based on user ability level [14], (5) the clear instruction of the product, (6) the ease on navigate of the product, (7) the balancing among the elements on the product (text, picture, audio, video or animation), (8) User friendly to use the product (9) aim to individual learning, (10) able to train the users learning domains (cognitive, affective and psychomotor), (11) balancing in selecting the element of colors in the product, (12) loaded the material in concise and substantive, and (13) task and competence exam training are appropriate with material in the product.

To produce a good adaptive mobile learning product need validation. The product validation is conducted by material expert, media expert and candidate users [6]. Developed adaptive mobile learning is claimed as feasible by the expert after the product meets the feasibility criteria which are divided into five assessment aspects; learning aspect, content aspect, completeness aspect, fidelity, and message, and language and ease to understand aspect. In the criteria of feasibility product test of media expert are easy to operate aspect, easy to navigate aspect, aspect of adaptive ability toward the student learning of users, display quality aspect, and illustration quality aspect.

Meanwhile, the advantages of developed product and feasible according to expert can measure through the user's response test. Moreover, competence task questionnaire is used to know the differences of learning outcome before and after the learning using adaptive mobile learning and the product's capability to support the blended learning process.

Blended learning is a combination of characters from both traditional/conventional learning and electronic and online learning environment. It merges aspect of blended elearning such as website learning based, streaming video, audio communication synchronous [7], and asynchronous web-based learning, internet-based learning, learning management system, massive open online courses (MOOCs) [5] [15], online learning [16], etc. with face to face learning.

The product advantages criteria based on user perspective are: easy to operate and navigate aspect, product interest aspect, support to blended learning process aspect, aspect of adaptive ability toward the differences of user learning styles and aspect of advantages of product.

\section{Methods}

\subsection{Research Data}

Data collection was carried out by conducting a survey using questionnaire both for validator expert and students as the user of the product. The data in this study were 37 records from two media experts and two material experts on alfa test, five students on beta test 1 and 29 students on the second beta test.

Instruments were divided into; questionnaire, interview, competence test task, and documentation. Questionnaire was filled by students on pre-survey, material experts, media experts, and student's user. The interview was conducted on pre-survey. Competence test task 
was used for pretest and posttest. And, documentation was used since pre-survey until the summative test.

The instrument has validated before to use to collect the data. The instruments are instrument for media experts, material experts, learning styles, and students. Meanwhile, the competency test task is validated by material expert together with material validation process.

Data types research was both qualitative and quantitative. Qualitative data is obtained from the need analysis result and interview on pre-survey. Qualitative data is obtained from media expert, material expert, and students through a questionnaire which is analyzed descriptively on four scales. And, quantitative data is obtained from pretest and posttest result of student learning outcomes.

The data is described as a consideration point to revise the adaptive mobile learning product. Moreover, the quantitative and qualitative data are used to measure the quality of product usefulness to support the learning process.

Data collection techniques are questionnaire, observation, interview, and competence test task. And the instruments in data collection are questionnaire, observation sheets, interview guideline, and items for pretest and posttest.

Qualitative data is suggestion and opinion from media expert, material expert, and students on beta 1 test. The data is collected and concluded to improve the quality of developed product. In contrast, quantitative data is questionnaire score from media expert, material expert, and students which is obtained from questionnaire on the Likert scale and convert into scale 4; strongly feasible, feasible, not feasible, and strongly not feasible.

The steps on Quantitative data analysis includes; (1) collecting the data; (2) scoring; (3) the score is converted into a score of scale four by using Mardapi's criteria.

Table 1. Scoring Reference Criteria

\begin{tabular}{|c|l|l|l|}
\hline Score & Formula & Scale & Category \\
\hline 4 & $\mathrm{X} \geq \overline{\mathbf{X}}_{+1 . \mathrm{SBx}}$ & $4 \mathrm{X}>3,00$ & $\begin{array}{l}\text { Strongly } \\
\text { Feasible }\end{array}$ \\
\hline 3 & $\overline{\mathbf{X}}_{+1 . S B x}>\mathrm{X} \geq \overline{\mathbf{X}}$ & $2,50<\mathrm{X} \leq 3,00$ & Feasible \\
\hline 2 & $\overline{\mathbf{X}}_{>\mathrm{X}} \geq \overline{\mathbf{X}}_{-1 . \mathrm{SBx}}$ & $2,00<\mathrm{X} \leq 2,50$ & Not Feasible \\
\hline 1 & $\mathrm{X}<\overline{\mathbf{X}}_{-1 . \mathrm{SBx}}$ & $\mathrm{X} \leq 2,00$ & $\begin{array}{l}\text { Strongly not } \\
\text { feasible }\end{array}$ \\
\hline
\end{tabular}

\subsection{Research Procedures of Alessi Trollip Models}

The particular research used research and Development (R \& D) approach. This research aimed to develop an adaptive mobile learning product on learning media Android-based for student Senior High School/Islamic High School grade XI of Science. The model of R\&D in the particular research adopted the model of Stephen M. Alessi dan Stanley R. Trollip [17]. Generally, there are three steps; planning, design, and development

Planning phase includes define the field/scope, identify the student characteristic, make the planning document, decide and collect the sources, perform the brainstorming. Planning phases includes conduct the concept analysis and material scope, decide the program component, make flowchart and storyboard, decide the software in developing process. Development phase includes the preparation of the material document, combine the media 
parts (text, audio, video, animation, and picture) and combine materials to make the adaptive mobile learning program until do not find any bug and error which show the adaptive mobile learning are ready to continue to test by Alfa test. Alfa test is conducted by two media experts and two material experts. After that, the beta 1 test is conducted to 5 students as the users. Beta 2 test is conducted on small group (one class) to know the users' opinion on the developed product. The last develeped produst is conducted by applying pretest and posttest on beta test participant in order to compare the product usefulness to achieve the learning goal; reaching the minimum target.

\section{Research Result and Discussion}

Research result of this research and development is a learning multimedia program adaptive mobile learning on Biology subject of Senior High School. The developed Program is an android application.

The difference between adaptive mobile learning and mobile learning is on the feature of user learning style test. By this feature, the user will direct to test for learning style before accessing the material menu.

The instrument of learning style adopted from instrument test of visual, auditorial and kinesthetic (VAK) developed by Victoria Chisslet \& Alan Chapman [11]. They are 25 number of tasks.

After the product has finished, then continue to product validation by material expert and media expert. The validation has purpose to measure and assess the material validation degree and the learning aspect of Adaptive Mobile Learning ( $A-M o L)$. The validation has purpose to produce a good and feasible product on the aspect of material and learning.

Generally, four aspects validated by material expert; learning aspect, content validity aspect, completeness aspect, fidelity and message of the material, and easy to understand and language aspect in the product of Adaptive Mobile Learning (A-MoL).

Next, media validation aims to measure the feasibility degree of the product. The instrument is given to media experts to assess the media quality. Media validation is divided into five aspects; first, easy of media operation aspect; second, easy on navigation; third, adaptive ability to user learning style; fourth, display quality; and fifth, illustration quality.

Chart of material expert validation shows the score of validation result of material expert is on strongly feasible category based on the average score of 3.62. The score is obtained based on the average validation score of each aspect; learning aspect has average score of 3.79 on strongly feasible category, content completeness aspect has average score of 3.70 on strongly feasible category, aspects of completeness, fidelity, and material have average score of 3.25 on strongly feasible category, and aspects of ease to understand and language have average score of 3.75 on strongly feasible category.

The result of media expert validation shows the total score validation from two media experts that gained an average score of 3.54 and the score is on strongly feasible category. The average score explained on each aspect; first, easy of media operation aspect consisted of six items indicator, gained an average score of 3.50 with strongly feasible category. Second, aspect of ease on navigation consisted of four items indicator, gained an average score of 3.75 with strongly feasible category. Third, the adaptive ability to users' learning style consisted of four items indicator, gained an average score of 4 with strongly feasible category. Then, display quality aspect consisted of six items indicator, gained an average score of 3.50 with 
strongly feasible category. And, illustration quality aspect consisted of seven items indicator, gained an average score of 3.43 with strongly feasible category.

The beta test 1 result; tested to 5 students of Adaptive Mobile Learning $(A-M o L)$ user, it gained an average score of 2.99 with strongly feasible category on 5 aspects. By the detail, aspect of ease to operate and navigating the program, five users gave score good/feasible on eight items indicator with an average score of 2.60. Meanwhile, aspect of program interest, five users gave score good/feasible on four items indicator with average score of 2.85 .

Based on data of product test result in the group beta 2 tests, it obtained average score of 3.26 with very good/ feasible. In the detail, the aspect ease in operating and navigating program, the entire sample of beta test gave score of very good/ feasible on eight items indicator with average score of 3.15. Meanwhile, the aspect of program interest, the entire sample beta 2 test gave score very good/ feasible on four items indicator with average score of 3.20 .

Cognitive competence test to student of grade XI IPA 3 SMAN 1 Depok, Sleman, Special Region of Yogyakarta as user of Adaptive Mobile Learning (AMoL), was conducted on pretest dan posttest. Then, data of pretest and posttest was compared to find out the significance increasing of learning outcomes between pretest and posttest before and after using the developed program. The table of data comparison of cognitive competence test is presented on table 1 [18].

Table 2. Data Comparison Of Cognitive Competence Test On Pretest And Posttest

\begin{tabular}{llcc}
\hline No & Variable & Pretest & Posttest \\
\hline 1 & Lower Score & 15 & 75 \\
2 & Highest Score & 75 & 100 \\
3 & Average Score & 53,93 & 87,69 \\
& Total of Differences score & \multicolumn{2}{c}{$\mathbf{3 3 , 8}$}
\end{tabular}

The visual data of competence test assessment on beta 2 test to student of Adaptive Mobile Learning (AMoL) user is presented in figure 1.

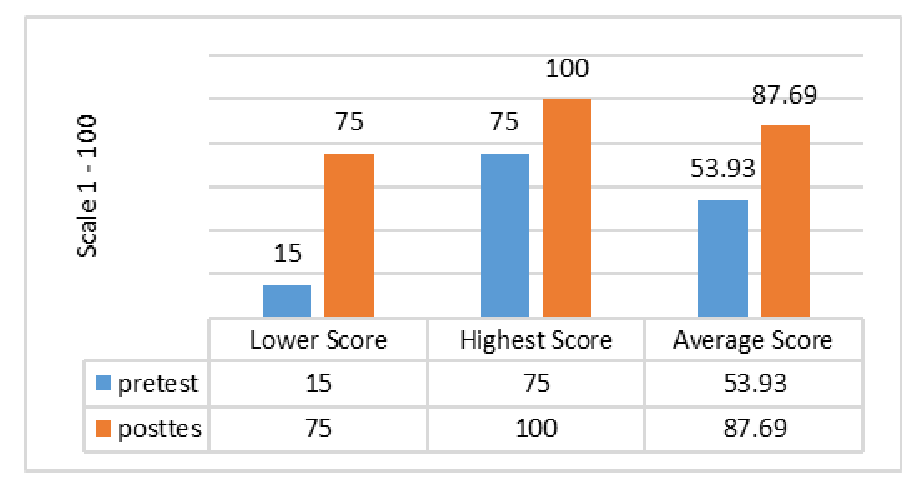

Figure 1. Diagram of Data Comparison on Pretest and Posttest.

Based on data analysis on pretest and posttest on figure 1, there are increasing score of competence before and after using program Adaptive Mobile Learning (AMoL). In summary, 
indicator of learning completeness has been achieved. It based on data that all students obtained the minimum average score of 75 .

The visual data of comparison of pretest and posttest average scores based on learning style groups of Adaptive Mobile Learning (AMoL) is presented in figure 2.

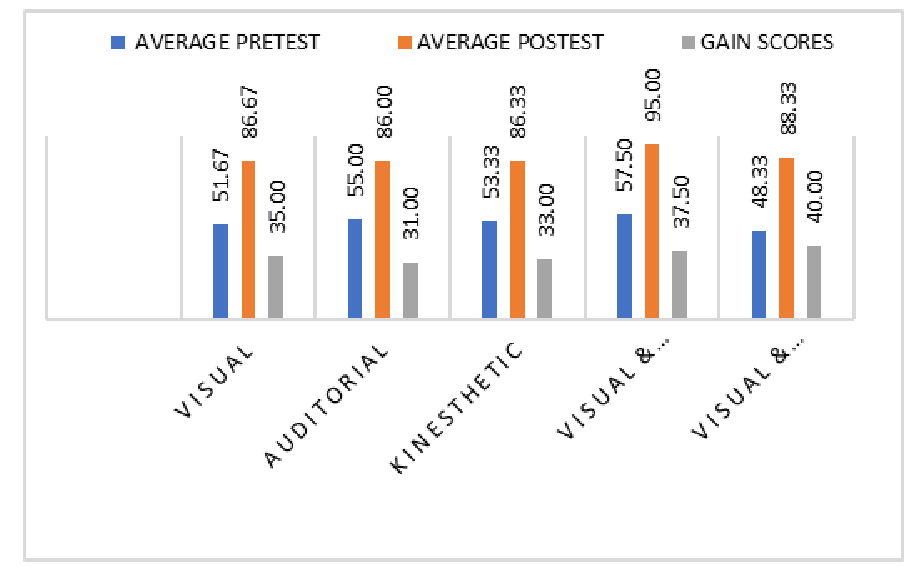

Figure 2. Comparison of Pretest and Posttest Average Scores based on Learning Style Groups

Based on the data of average score on group of visual learning style, there is comparison score between pretest and posttest on each learning style group of user Adaptive Mobile Learning $(A-M o L)$. Generally, the average posttest score has increased up to $30 \%$. But, the increasing percentage is different on each learning style. The increasing of posttest average score on visual learning style is $35 \%$. The increasing of posttest average score on audio learning style is $31 \%$. The increasing of posttest average score on kinesthetic learning style is $33 \%$. Meanwhile, the increasing of posttests score of audio-visual learning style is 37.50 , and the highest score of increasing average posttest is visual kinesthetic learning style of $40 \%$.

\section{Conclusion}

Based on the research and development, concluded that Adaptive Mobile Learning (A$M o L)$ on Biology Subject SMA claimed as feasible category to be used as learning media based on material and media, and user's response on beta 1 and 2 test. The feasibility category is according to average score by material expert is 3.62 with very feasible category, the average score by media expert is 3.53 with very feasible category, average score of beta 1 test is 2.99 with feasible category, and average score of beta 2 test is 3.29 with very feasible category. Adaptive Mobile Learning (A-MoL) product is claimed having beneficial and proven by the increasing of learning outcome of 33.80. The average score of pretest is 53.93, increased to 87.69 in posttest with percentage of $\mathrm{KKM}$ is $100 \%$. Moreover, according to expert and student, the product can support the quality of blended learning process with average score of 3.42 and very feasible category.

The product of Adaptive Mobile Learning ( $A-M o L)$ needs to further implement on broad field. Hope, students and teachers both in informal or formal education use Adaptive Mobile 
Learning $(A-M o L)$ program in facilitating the learning process. Consider developing other material, especially support the learning through mobile learning approach. Able well facilitating the differences of student learning style characteristic beside visual, audio and kinesthetic learning style, such as global learning style, analytic, and read-write learning style. The development of Adaptive Mobile Learning $(A-M o L)$ in facilitating material delivering to student, consider to the student characteristic such knowledge, area, and students' condition in mastery the material.

Acknowledgements. This paper in conjuction with the The 3rd International Conference on Indonesian Economy \& Development (ICIED 2018).

\section{References}

[1] I. N. S. Degeng, Variable class learning science for theory and research development, Bandung: Aras Media, 2013.

[2] Daryanto, Learning media is very important role in achieving learning goals, Yogyakarta: Gaya Media, 2010.

[3] R. E. Mayer, Multimedia learning prinsip-prinsip dan aplikasi., Newyork: Cambrigde University Press, 2009.

[4] C. Zhu, "Student Satisfaction, Performance, and Knowledge Construction in Online," Educational Technology and Society, vol. 15, no. 1, pp. 127-136, 2012.

[5] M. L. Waugh dan J. Su, "Student Perceptions of a Successful Online Collaborative Learning Community," Journal of Interactive Online Learning , vol. 14, no. 1, pp. 29-44, 2016.

[6] H. D. S. Ence Surahman, "Development of adaptive mobile learning in high school biology subjects as an effort to support the blended learning process," Jurnal Inovasi Teknologi Pendidikan, vol. 4, no. 1, pp. 26-37, 2017.

[7] A. Bartolomé, L. Castañeda dan J. Adell, "Personalisation in educational technology: the absence of underlying pedagogies," International Journal of Educational Technology in Higher Education, pp. 1-17, 2018.

[8] Ö. Özyurt dan H. Özyurt, "Learning style based individualized adaptive e-learning environments: Content analysis of the articles published from 2005 to 2014," Computers in Human Behavior, , vol. 52, p. 349-358, 2015.

[9] H. C. Huang, T. Y. Wang dan F. M. Hsieh, "Constructing an Adaptive Mobile Learning System for the Support of Personalized Learning and Device Adaptation," Procedia - Social and Behavioral Sciences, vol. 64, p. 332-34, 2012.

[10] C. Luhrs dan L. M. Salas, "Collaboration Levels in Asynchronous Discussion Forums: a Social Network Analysis Approach," Journal of Interactive Online Learning m, vol. 14, no. 1, pp. 1-16, 2016.

[11] A. Canfield dan W. Knight, "Learning Style Inventory," Los Angeles: CA: Western Psycological Services, 1983.

[12] D. Wahyuningsih dan C. A. Budiningsih, "Implementation Blended Learning by the Constructive Approach (BLCA) dalam Pembelajaran Interaksi Manusia dan Komputer," Jurnal Inovasi Teknologi Pendidikan, vol. 1, no. 1, p. 15-27, 2014.

[13] Sugiyarto, "Mobile Learning Media Development 'Chem Edu' Based on Android as Chemical Material Supplement Based on 2013 Curriculum to Improve Academic Performance of High School / MA Students," UNY, Yogyakarta, 2014.

[14] J. M. Spector, Smart Learning Environtment: Concept and Issues., SITE, 2016. 
[15] K. Ryan, "Creating Collaborative Learning Spaces," Technology \& learning, vol. 36, no. 7, pp. 30-33, 2016.

[16] S. Bailey, S. Hendricks dan S. Applewhite, "Student Perspectives of Assessment Strategies in Online Courses," Journal of Interactive Online Learning, vol. 13, no. 3, pp. 112-125, 2015.

[17] S. M. Alessi dan S. R. Trollip, "Multimedia for Learning Methods and Development," Toronto: Allyn and Bacon, 2001.

[18] D. Mardapi, "Techniques for preparing test and non-test instruments," Yogyakarta: Mitra Cendekia Jogjakarta Press, 2008. 